\title{
Karakteristik Fasad Gedung De Majestic Braga Karya C.P. Wolff Schoemaker
}

\author{
Meta Riany ${ }^{1}$, Rio Nuryadi ${ }^{1}$, Ilham Apriyandi ${ }^{1}$, Aidil Akbar ${ }^{1}$ \\ Program Studi Arsitektur, Fakultas Arsitektur dan Desain \\ Itenas, Institut Teknologi Nasional Bandung \\ Email: tari@itenas.ac.id
}

\begin{abstract}
ABSTRAK
C. P. Wolff Schoemaker adalah seorang arsitek Belanda yang menghasilkan banyak bangunan pada masa kolonialisasi Belanda. Hasil karyanya tersebar di berbagai kota besar di Indonesia, salah satunya adalah gedung De Majestic yang terletak di kawasan cagarbudaya jalan Braga Bandung. Lamanya beliau berprofesi sebagai arsitek telah menghasilkan berbagai fungsi bangunan baik bangunan milik pemerintahan maupun swasta. Disain bangunannya tampak similar terutama pada fasad bangunannya sehingga menarik untuk dikaji lebih dalam karakteristik dari elemen pembentuk fasadnya. Studi ini dimulai dengan mempelajari karya-karya beliau melalui buku, foto dan situs internet dan kemudian mempelajari lebih dalam pada karya beliau yang berada di kota Bandung. Perkembangan karya beliau dapat digolongkan ke dalam 3 periode waktu sejak tahun 1918 hingga 1940 an berdasarkan elemen-elemen pembentuk fasad bangunannya. Gedung de Majestic dipilih sebagai studi kasus karena fungsinya yang berbeda (bioskop) dan berlokasi di jl Braga yang kental dengan karakter arsitektur Kolonial di kota Bandung. Bangunan ini merupakan hasil karya C.P Wolf Schoemaker pada periode ke 2 yang mulai memadukan arsitektur Eropa dan unsur lokal arsitektur Indonesia. Diharapkan dengan memahami sejarah bangunan dapat memberikan ide kepada para arsitektur muda untuk mencintai dan menerapkan ciri khas budaya lokal Indonesia yang unik, menarik, variatif pada karakter karya-karya mereka.
\end{abstract}

Kata kunci: C.P. Wolff Schoemaker, Elemen Fasad Bangunan, Gedung De Majestic, Karakteristik Bangunan

\begin{abstract}
C. P. Wolff Schoemaker is a Dutch architect who produced many buildings during the Dutch colonial era. His work is scattered in various big cities in Indonesia, one of it is De Majestic building, which is located in the cultural heritage area of Braga street, Bandung. The duration of his work as an architect has produced a variety of building functions both owned by government or private buildings. The design of the building looks similar, especially on the building façade, so it is interesting to study more deeply of characteristics of the elements that create the building's facade. This study begins by studying his works through books, photos and internet sites and then learn more into his works in the city of Bandung.The development of his works can be classified into 3 time periods from 1918 to 1940 based on the development of building's facade elements. De Majestic building was chosen as a case study because of its different function (cinema) and it located on Jalan Braga which has a strong colonial character in the city of Bandung. This building is the work of C.P Wolff Schoemaker in the 2 nd period which began to combine European architecture and local elements of Indonesian architecture. It is hoped that understanding the history of the building can provide ideas for young architecture to love and apply the unique, interesting, and varied characteristics of Indonesian local culture to the character of their works.
\end{abstract}

Keywords: C.P. Wolff Schoemaker, Building's characteristics, De Majestic Building, Element of Building Facade 


\section{PENDAHULUAN}

Dalam masa kolonialisasi yang hampir 200 tahun di Indonesia, bangsa Belanda memberikan banyak pengaruh kepada masyarakat Indonesia baik dibidang politik, ekonomi, sosial dan budaya serta gaya arsitektur bangunannya. Pada masa awal kedatangannya pemerintah kolonial Belanda mendirikan bangunan-bangunan dengan gaya arsitektur Eropa yang dapat dibedakan dari bentuk, ukuran dan material yang berbeda dengan bangunan-bangunan di Indonesia pada saat itu.

Seiring dengan berjalannya waktu terjadi perkembangan gaya arsitektur dari bangunan kolonial yang mulai beradaptasi terutama pada iklim tropis yang sangat berbeda dengan iklim di negara asal mereka, Belanda. Selain itu keindahan dari budaya dan alam Indonesia mulai dilihat sebagai potensi untuk mendisain sebuah bangunan yang menampilkna ciri khas budaya lokal. Hal ini terlihat pada bangunanbangunan pemerintah terutama yang didirikan pada periode berikutnya, sekitar tahun 1920 an yang menerapkan gaya Indische Architektuur, yaitu perpaduan gaya Eropa dan Indonesia [1]. Salah satu arsitek yang menerapkan gaya ini dan banyak menghasilkan karya adalah C.P Wolff Schoemaker.

C.P Wolff Schoemaker adalah seorang arsitek berkebangsaan Belanda yang lahir di Banyu Biru, Semarang, Jawa Tengah- Indonesia pada tahun 1882. Karya-karya beliau diawali dengan mendirikan bangunan-bangunan pemerintah Belanda yang memang menjadi prioritas pada masa tersebut. Karyanya tersebar di berbagai kota besar di Indonesia seperti di Malang, Surabaya, Semarang, Medan, Bandung, Jakarta dan beberapa lokasi lain. Seiring dengan berjalannya waktu karya beliau mengalami perkembangan, terutama dalam penerapan gaya arsitekturnya. C.J van Dullemen (2010) dalam bukunya yang berjudul "Tropical Modernity; The Life \& Work of C.P. Wolff Schoemaker" mencoba memetakan karakteristik dari karya-karya C.P Wolff Schoemaker kedalam 3 periode waktu sejak tahun 1918 sampai dengan akhir masa kolonialisasi Belanda di Indonesia, tahun 1940 an. [2]

Dalam bukunya, C.J van Dulleman mempelajari mengenai perkembangan gaya arsitektur yang diterapkan pada bangunan-bangunan karya C.P Wolff Schoemaker. Perkembangan tersebut terutama dapat dikenali pada bentuk dan karakteristik elemen fasad bangunannya yang semula bernuansa Eropa kemudian berubah dengan memadukan kekayaan lokal Indonesia, seperti penerapan variasi elemen flora dan fauna. Perpaduan karakter Eropa dan Indonesia kemudian berkembang dengan menerapkan 'Kala', yaitu muka dengan kepala raksasa yang umumnya dijumpai pada pintu candi-candi di Jawa [3] 'Kala' kemudian menjadi salah satu karakteristik pada fasad bangunan-bangunan hasil karya C.P Wolff Schoemaker.

De Majestic yang didirikan tahun 1922 dan berlokasi di kawasan cagar budaya Jl Braga Bandung merupakan salah satu bangunan hasil karya C.P Wolff Schomaker yang dinilai menarik untuk dikaji lebih dalam. Gedung ini didirikan sebagai bioskop untuk para elit Belanda guna melengkapi jalan Braga yang merupakan pusat perbelanjaan dan pusat mode di Hindia Belanda yang dikenal dengan sebutan Parijs van Java [4], Gedung De Majestic telah beberapa kali mengalami pergantian nama dan fungsi. Pada saat didirikan gedung ini diberi nama Concordia Bioscoop dan kemudian masih di era yang sama berganti nama menjadi Majestic Bioscoop. Setelah kemerdekaan gedung ini beralih nama menjadi Oriental Bioskop dan kemudian masih dengan fungsi yang sama berubah menjadi Bioskop Dewi, Pada tahun 2002, gedung Bioskop Majestic direvitalisasi dan dialihfungsikan sebagai gedung serba guna untuk kegiatan pertemuan, pameran serta pertunjukan musik dan berganti nama menjadi Asia Africa Cultural Center (AACC), kemudian berganti nama menjadi New Majestic dan hingga saat ini nama gedung tersebut berubah lagi menjadi De Majestic [5]. 


\section{METODOLOGI}

Kondisi pandemic yang masih berlangsung hingga saat ini tidak memungkin kami untuk meninjau langsung objek studi ke lapangan, Oleh karenanya digunakan data sekunder yang diperoleh dengan melakukan studi pustaka melalui situs internet. Beberapa buku sejarah mengenai biografi C.P Wolff Schoemaker dan karya-karyanya baik didalam maupun diluar negeri menjadi pegangan. Sejarah bangunan De Majestic dan sejarah kota Bandung, khususnya kawasan jalan Braga juga menjadi data tambahan, Sedangkan teori arsiektur terkait pembahasan fasad juga diperoleh dari literatur dan situs internet. Dikaji pula penelitian-penelitian terdahulu yang dapat diperoleh dengan mengakses jurnaljurnal dari berbagai situs yang terpecaya untuk mendapatkan data sekunder yang kemudian di analisis dan dikaji serta dituangkan dalam kesimpulan mengenai Karakteristik Gedung De Majestic Bandung,

Krier (1983) mengatakan bahwa fasad merupakan elemen arsitektur terpenting yang mampu menyuarakan fungsi dan makna sebuah bangunan [6]. Fasad tidaklah semata-mata mengenai memenuhi "persyaratan alami" yang ditentukan oleh organisasi dan ruang dibaliknya tetapi fasad menyampaikan keadaan budaya saat bangunan itu didirikan. Selain itu fasad juga mengungkap kriteria tatanan dan penataan serta memberikan kemungkinan dan kreativitas dalam ornamentasi dan dekorasi bangunan. Dinyatakan pula bahwa fasad adalah representasi atau ekspresi dari berbagai aspek yang muncul dan dapat diamati secara visual. Dalam konteks arsitektur kota, fasad bangunan tidak hanya bersifat dua dimensi akan tetapi bersifat tiga dimensi yang dapat merepresentasikan masing-masing bangunan dalam kepentingan publik (kota) atau sebaliknya.

\section{HASIL DAN PEMBAHASAN}

Untuk mengetahui karakteristik elemen fasad pada gedung De Majestic, maka penelitian ini akan meninjau elemen-elemen pembentuk fasad seperti yang dituliskan Krier (1983) [6], yang meliputi:

\subsection{Gerbang dan Pintu Masuk}

Bentuk geometris berupa tabung dan diletakkan menjorok ke arah jalan yang mengisyaratkan kepada pengunjung bahwa area tersebut merupakan pintu masuk atau main entrance dari gedung tersebut. Penempatan masa yang menyerupai tabung ini diposisikan berada di garis as masa bangunan utama yang membagi sisi kiri dan kanan gedung De Majestic secara simetris (gambar1).

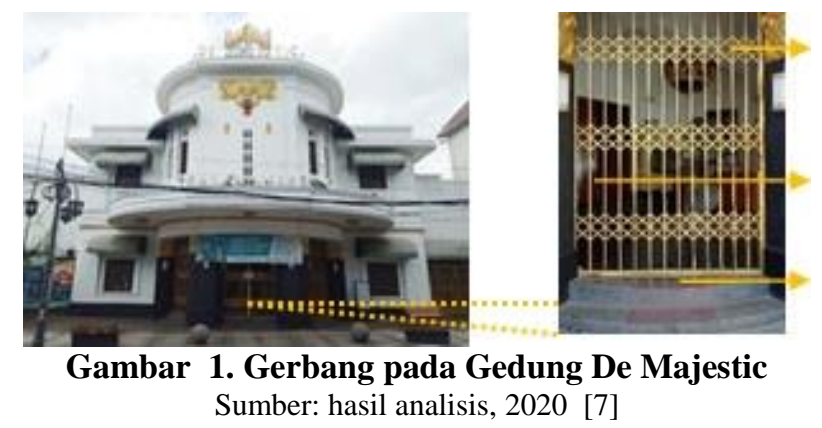

Bentuk dan perletakan posisi tabung pada gedung De Majestic diterapkan pula oleh C.P Wolf Schoemaker pada rancangan sebuah villa untuk keluarga Kan dan Villa Isola di Bandung (gambar 2). 

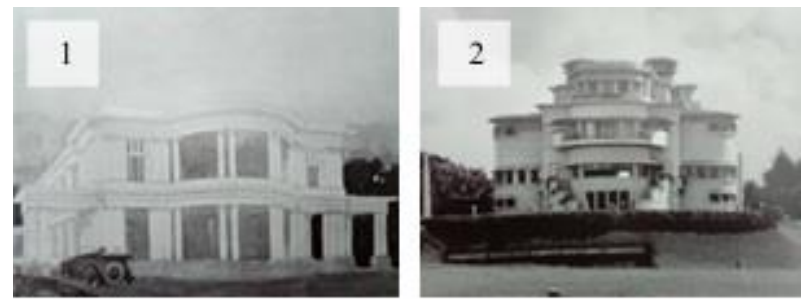

Gambar 2. Villa for Kan Family (1), Villa Isola (2)

Sumber: Modernity "Life and Works of C.P. Wolf Schoemaker" [2]

\subsection{Zona Lantai Dasar}

Pada gedung De Majestic zona lantai dasar dibuat dengan level lebih tinggi dari area luar sehingga diperlukan beberapa anak tangga untuk mencapai lobby. Peninggian level ini memisahkan zona lobby dengan area luar. Selain dengan perbedaan level lantai, perbedaan antara zona lobby dan ruang luar juga dapat dilihat dari pola lantai yang digunakan, lantai di area lobby menggunakan lantai ubin dengan motif floral sedangkan bagian luar menggunakan lantai ubin polos, tanpa motif (gambar 3).

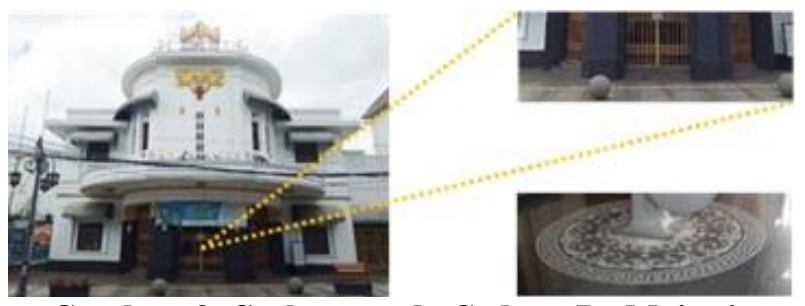

Gambar 3. Gerbang pada Gedung De Majestic Sumber: hasil analisis, 2020 [7]

Disain serupa diterapkan pula oleh C.P Wolff Schoemaker pada 3 karya lainnya, yaitu: Gedung Merdeka, Villa Merah, dan Boscha Observatory, seperti tertera pada gambar 4.
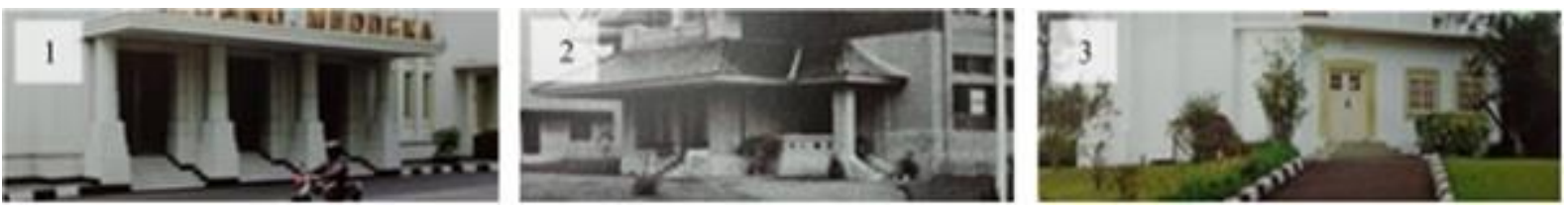

Gambar 4. Gedung Merdeka (1), Villa Merah (2), Boscha Observatory (3)

Sumber: Buku Tropical Modernity "Life and Works of C.P. Wolf Schoemaker" [2]

\subsection{Jendela dan Pintu Masuk Bangunan}

a. Jendela

Terdapat beberapa bukaan di bagian atas'tabung' Gedung De Majestic yang berfungsi memberikan penerangan ke lobby. Selain itu diterapkan pula beberapa jendela di fasad kiri, kanan, baik di atas maupun bawah yang semuanya menggunakan kusen yang diberi profil sebagai variasi atau penghias jendela, seperti terlihat pada gambar 5 .

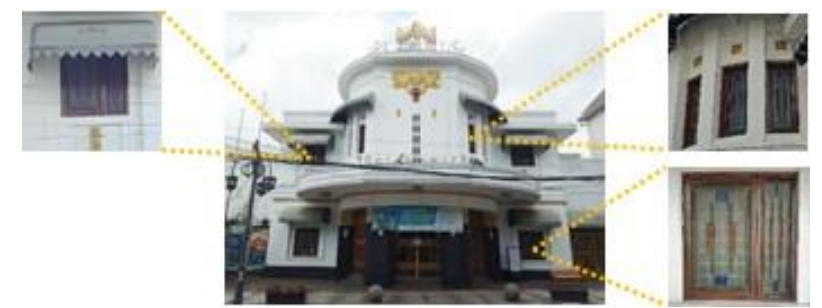

Gambar 5. Jendela pada Gedung De Majectic

Sumber: hasil analisis, 2020 [7] 
Model jendela seperti pada gedung De Majestic juga diterapkan pada gedung karya-karya Schoemaker lainnya, seperti pada gedung Societa Commisionaria di Esportazione e di Importazione Orientale Agency, Bosscha Observatory dan Villa of C. P. Wolff Schoemaker, seperti tertera pada gambar 6.
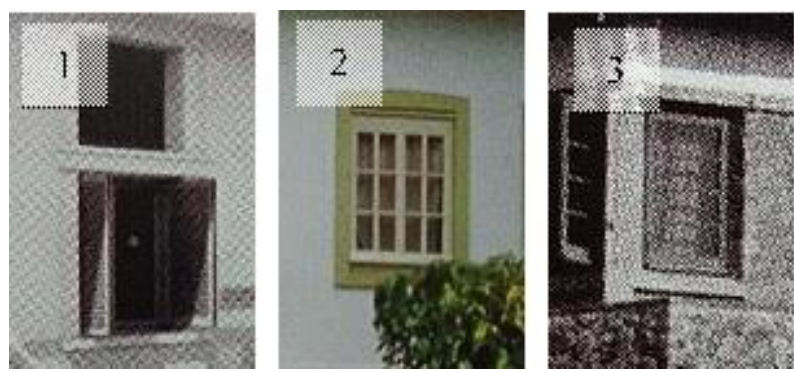

Gambar 6. Societa Commissionaria di Esportazione e di Importazione Orientale Agency (1), Bosscha Observatory (2) serta Villa of C. P. Wolff Schoemaker (3)

Sumber: Tropical Modernity "Life and Works of C.P. Wolf Schoemaker" [2]

Selain itu, elemen lain yang mencirikan karakteristik karya Schoemaker adalah pengulangan penempatan jendela. Jendela ditempatkan lebih menjorok ke dalam, rata dengan dinding dalam sehingga memberi penegasan sebagai elemen vertikal. Hal ini diterapkan pula pada gedung karyakarya Schoemaker lainnya [2], seperti tertera pada gambar 7.
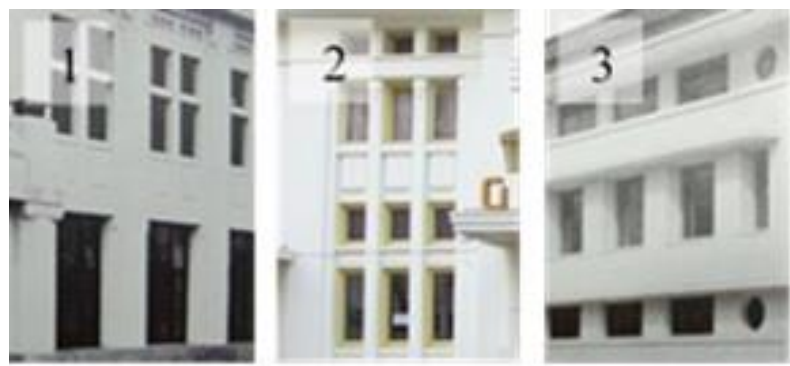

Gambar 7. Jaarbeurs Exhibition (1), Centre Concordia Club (2), Nederlandsch Indische Handelsbank (3) Sumber: Tropical Modernity "Life and Works of C.P. Wolf Schoemaker" [2]

\section{b. Pintu Utama}

Setelah melewati entrance utama dari gedung De Majestic, terdapat sebuah pintu berukuran besar menuju ke ruang dalam (gambar 8). Pintu tersebut menggunakan material kayu jati dengan kualitas prima yang tahan lama. Daun pintu tidak dibiarkan polos tetapi diberi bingkai dan bagian dalamnya diberi motif berupa grid atau pola kotak-kotak.

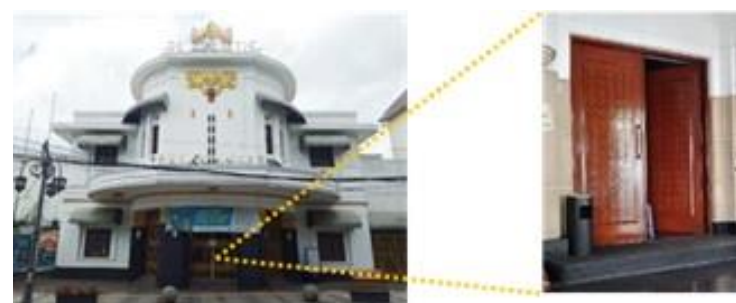

Gambar 8. Pintu pada Gedung De Majestic Sumber: hasil analisis, 2020 [7]

Hal serupa diterapkan pula pada daun-daun pintu pada gedung karya-karya Schoemaker seperti pada Gereja Bethel dan Gereja Katedral Santo Petrus, seperti terlihat pada gambar 9. 

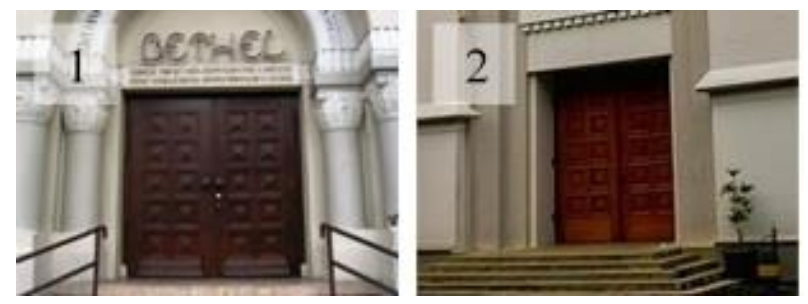

Gambar 9. Gereja Bethel (1), Gereja Katedral Santo Petrus (2)

Sumber: gpibbethel.wordpress.com, diunduh tanggal 24-Februari-2021 [8]

\section{c. Ventilasi (Lubang Angin)}

Gedung De Majestic mempunyai lubang angin yang terdapat dibagian fasadnya. Lubang angin berderet tepat di tengah tabung dari atas sampai ke leufel atau dak beton. Deretan lubang angin tersebut menjadi aksen yang mempertegas garis aksis pada fasad bangunan gedung De Majestic (gambar 10).

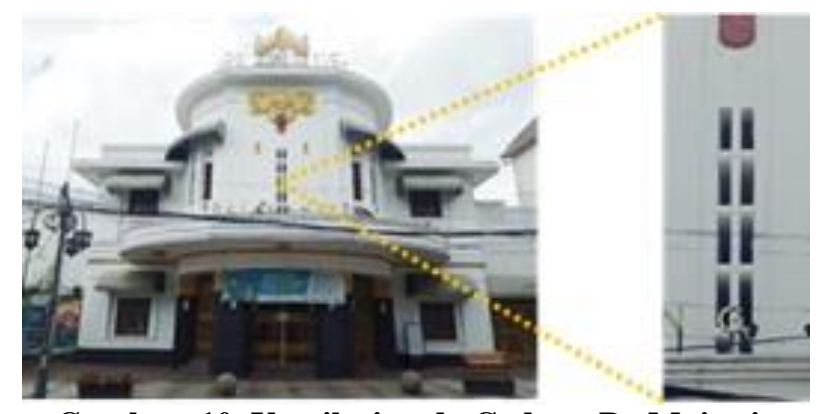

Gambar 10. Ventilasi pada Gedung De Majestic Sumber: hasil analisis, 2020 [7]

\subsection{Pagar Pembatas (Railing)}

Gedung De Majestic berhimpitan dengan bangunan milik Bandung Creative City Forum. Untuk menandakan bahwa kedua bangunan tersebut sudah berbeda fungsi, maka diberi railing atau pembatas berupa garis vertikal berwarna hitam (gambar 11).
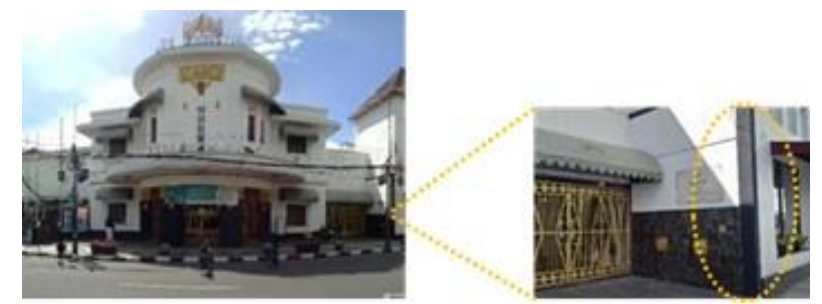

Gambar 11. Pagar Pembatas pada Gedung De Majestic Sumber: hasil analisis, 2020 [7]

Pembatas tersebut bukan merupakan bagian orisinil dari desain Schoemaker, karena dari dokumentasi ditemukan foto eksisting Gedung De Majestic saat berubah fungsi menjadi Asia Africa Cultural Centre (AACC) [9], periode tahun 2002-2010, belum terlihat adanya pembatas antara gedung De Majestic dengan bangunan disebelahnya (gambar 12).

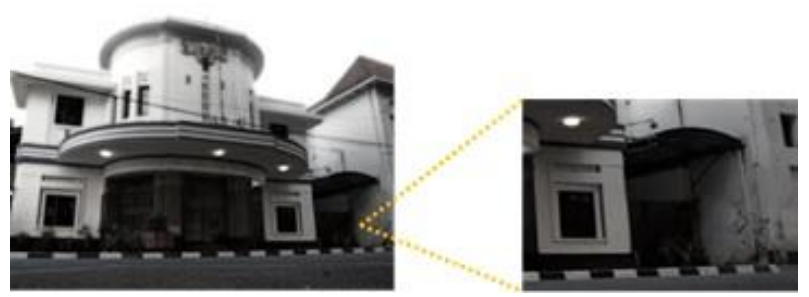

Gambar 12. Kondisi Pagar Pembatas saat Periode Tahun 2002 -2010 


\subsection{Atap \& Akhiran Bangunan}

\section{a. Akhiran Bangunan}

Jenis atap yang digunakan pada gedung De Majestic yaitu atap pelana. Penggunaan atap tersebut sebagai respon terhadap iklim di tropis Indonesia. Sedangkan, material penutup atapnya menggunakan seng bergelombang. Pada gedung De Majestic, Schoemaker menempatkan atap dibalik parapet sehingga akhiran bangunan pada gedung ini sebetulnya bukanlah atap, melainkan parapet yang mengelilingi fasad bangunannya (gambar 13).
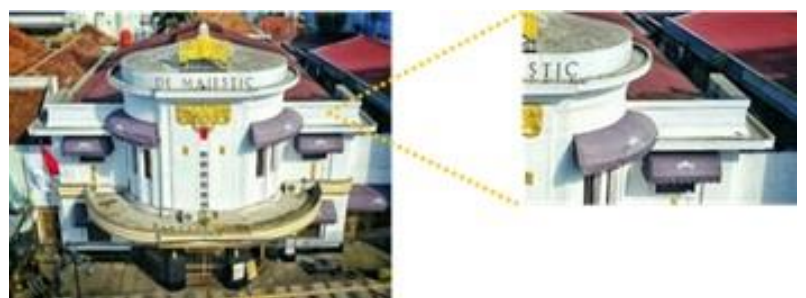

Gambar 13. Akhiran Bangunan pada Gedung De Majestic

Sumber: https://twitter.com/DeMajesticBdg/status/948440342407213057/photo/1 diunduh tanggal 24-Februari-2021 [10]

Penggunaan parapet ternyata diaplikasikan juga pada beberapa gedung lainnya, seperti Jaarbeurs Exhibition Centre, Concordia Club serta Van Dorp Office Bookshop and Print Shop. Sama seperti pada gedung De Majestic, Schoemaker merancang beberapa bangunan tersebut menggunakan atap miring, namun atap bangunannya ditutup oleh parapet yang mengelilingi bangunan tersebut (gambar 14).
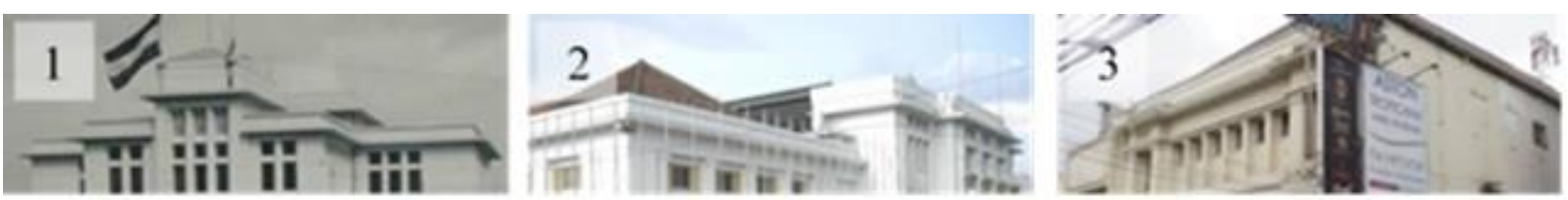

Gambar 14. Jaarbeurs Exhibition Centre (1), Concordia Club (2), Van Dorp Office Bookshop and Print Shop (3)

Sumber: Berbagai Sumber

\section{b. Tritisan (Kanopi Beton)}

Pada fasad gedung De Majestic, terlihat adanya tritisan yang terbuat dari beton. Tritisan tersebut tepat berada di atas pintu masuk bangunan serta bagian atas fasad bangunan, lebih tepatnya diatas bukaan jendela pada lantai dua (gambar 15).

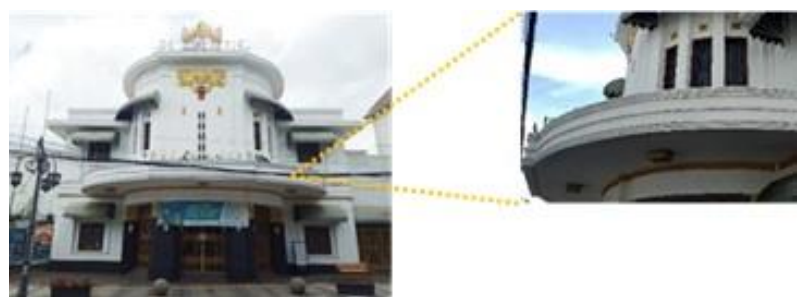

Gambar 15. Tritisan pada Gedung De Majestic Sumber: hasil analisis, 2020 [7] 
Penggunaan tritisan ternyata diaplikasikan juga pada sebagian besar karya arsitektur Schoemaker lainnya seperti gedung Concordia Club, Grand Hotel Preanger serta Villa Isola. Pada gedung-gedung tersebut, tritisan ditampilkan secara memanjang dan menerus mengelilingi fasad bangunan yang secara tidak langsung akan mempertegas garis horizontal pada fasad bangunan (gambar 16).
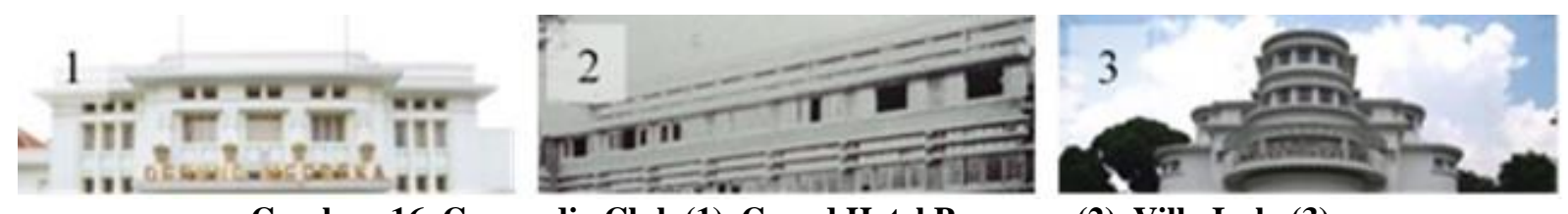

Gambar 16. Concordia Club (1), Grand Hotel Preanger (2), Villa Isola (3)

Sumber: Berbagai Sumber

\section{c. Awning (Kanopi Kain)}

Saat ini, terlihat adanya awning (kanopi kain) yang ditempatkan diatas beberapa jendela gedung De Majestic. Namun pada awal perancangannya, Schoemaker tidak merancang adanya awning pada gedung tersebut. Awning tersebut ditambahkan oleh pihak pengelola gedung De Majestic sekitar tahun 2010, sehingga, penggunaan awning pada gedung tersebut tidak dapat diklasifikasikan sebagai elemen arsitektur khas C. P. Wolff Schoemaker (gambar 17).

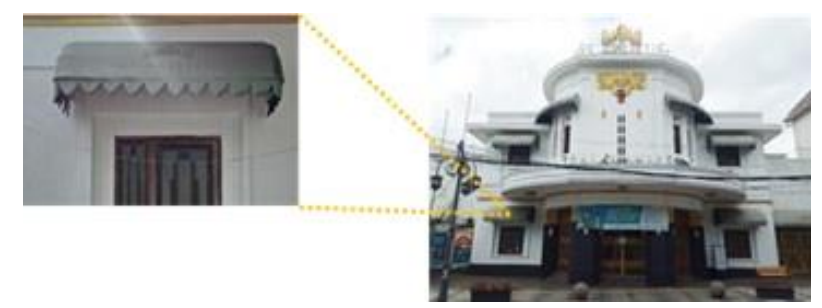

Gambar 17. Awning pada Gedung De Majestic Sumber: hasil analisis, 2020. [7]

\subsection{Tanda-tanda (Signs) \& Ornamen}

a. Tanda-tanda (Signs)

Seiring berjalannya waktu, gedung De Majestic telah mengalami beberapa kali pergantian nama dan fungsi bangunan. Fungsi awalnya adalah bioskop dan setelah kemerdekaan sd tahun 2002 bangunan ini tetap berfungsi sebagai bioskop meskipun sempat beberapa kali mengalami pergantian nama. Pada tahun 2002 gedung ini berganti nama menjadi Asia Africa Culture Centre (AACC) tetapi nama ini tidak bertahan lama karena pada 2010 diganti lagi menjadi New Majestic yang bertahan selama 7 tahun karena pada tahun 2017 sd sekarang gedung ini kembali menyandang nama De Majestic. (gambar 18)

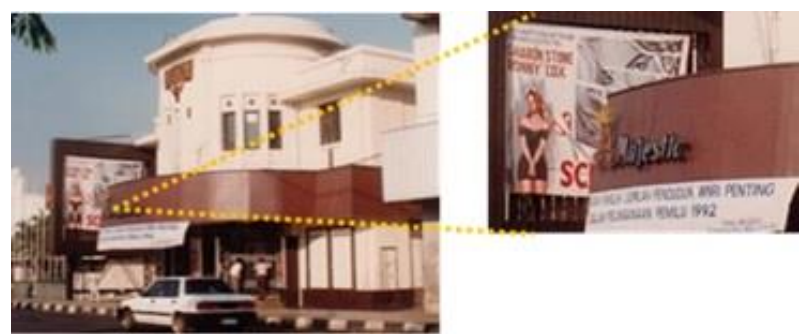

Gambar 18. Tanda-tanda pada Gedung De Majestic (1992)

Sumber: https://twitter.com/DeMajesticBdg/status/948440342407213057/photo/1 diunduh tanggal 24-Februari-2021 [10] 
Setiap kali terjadi perubahan fungsi dan nama gedung ini menambahkan sign (simbol) pada fasadnya yang mencerminkan fungsinya saat itu. Penambahan simbol yang berulang ini tidak dapat diklasifikasikan sebagai elemen arsitektur khas C. P. Wolff Schoemaker. (gambar 19)

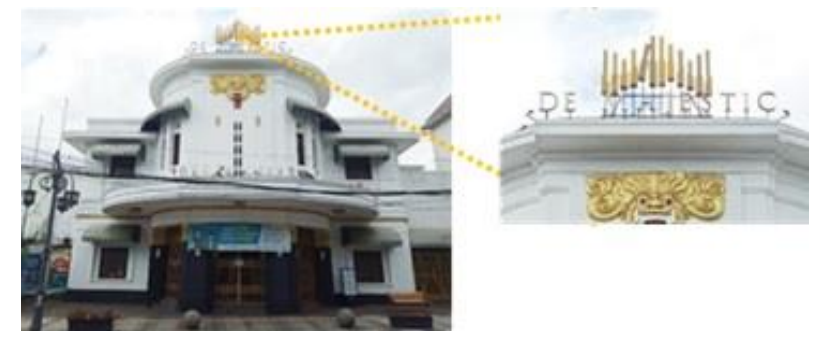

Gambar 19. Tanda-tanda pada Gedung De Majestic Sumber: hasil analisis, 2020 [7]

\section{b. Elemen Struktur (Balok)}

Balok pada bagan atap dari 'tabung' pada gedung De Majestic dibuat berundak-undak dan menjadi ornamen estetika fasad bangunannya. Balok tersebut dikenal dengan sebutan entablature. Pada gedung De Majestic entablature tidak ditampilkan secara rinci seperti pada karya-karya Arsitektur Klasik kebanyakan, tetapi entablature ditampilkan dengan bentuk yang lebih sederhana (gambar 20).

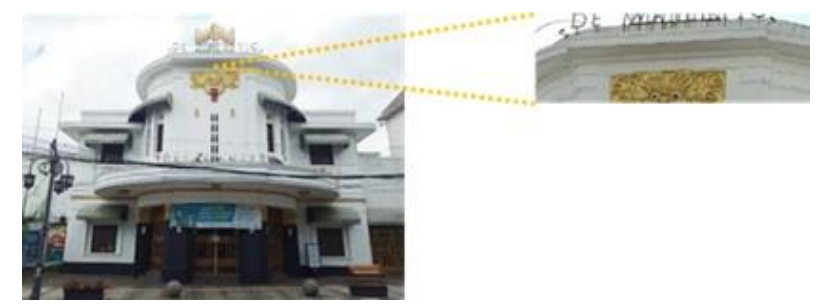

Gambar 20. Balok pada Gedung De Majestic Sumber: hasil analisis, 2020 [7]

Penggunaan entablature pada fasad bangunan ternyata hampir diaplikasikan di setiap karya arsitektur Schoemaker seperti pada Becker \& Co. Building, Van Dorp Office Bookshop and Print Shop serta Bosscha Observatory (gambar 21). Entrablature pada ke 3 gedung tersebut juga ditampilkan secara sederhana serupa dengan entablature pada gedung De Majestic.
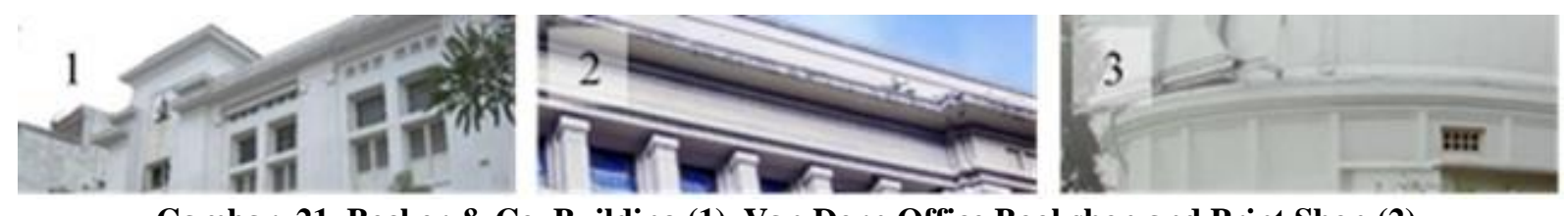

Gambar 21. Becker \& Co. Building (1), Van Dorp Office Bookshop and Print Shop (2),

Bosscha Observatory (3)

Sumber: Berbagai Sumber

\section{c. Elemen Struktur (Kolom)}

Kolom-kolom yang terdapat pada fasad gedung De Majestic diposisikan secara simetris. Empat buah kolom utama yang terdapat pada bagian tengah entrance bangunan dilengkapi dengan capital. Jika dilihat dari karakteristiknya, capital tersebut termasuk kedalam orde Corinthian. Capital yang terdapat pada gedung De Majestic berbentuk seperti lonceng yang terbalik dengan dilengkapi ornamen berupa daun Acanthus [7], seperti yang terlihat pada gambar 22. 

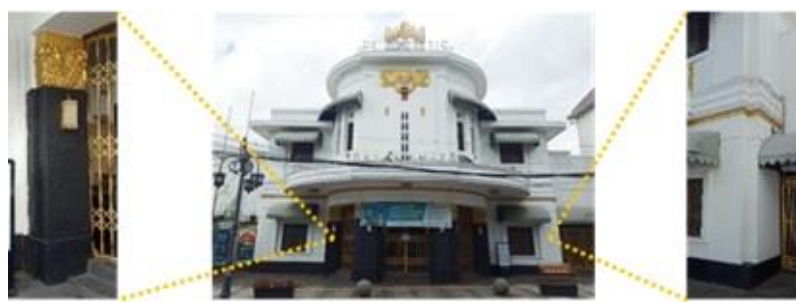

Gambar 22. Kolom pada Gedung De Majestic

Sumber: hasil analisis, 2020 [7]

Pada beberapa karya arsitektur lainnya, Schoemaker juga menerapkan penggunaan capital pada bagian fasadnya. Gaya dan jenis capital yang diterapkan sangat bervariasi mulai dari yang menyerupai orde Doric seperti pada gedung Nederlandsch Indische Handelsbank, orde Ionic seperti pada Jacobson, v.d. Berg \& Co. Office Building, orde Corinthian seperti pada A. C. Nix Building dan orde Romanesque seperti pada Protestant Bethel Church. Bahkan terdapat pula gaya dan jenis capital yang ditampilkan secara lebih modern dengan penggunaan motif yang lebih geometris dan sederhana seperti pada gedung Concordia Club yang dapat dilihat pada gambar 23 di bawah ini.
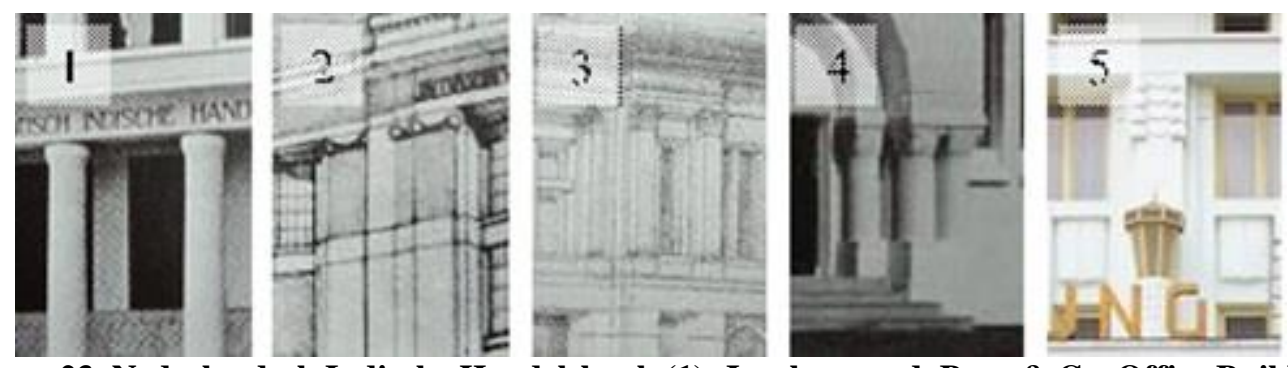

Gambar 23. Nederlandsch Indische Handelsbank (1), Jacobson, v.d. Berg \& Co. Office Buildin (2), A. C. Nix Building (3), Protestant Bethel Church (4), Concordia Club (5)

Sumber: Tropical Modernity "Life and Works of C.P. Wolf Schoemaker" [2]

\section{d. Ornamen Kala}

Pada gedung De Majestic Schoemaker menerapkan elemen tradisional lokal Indonesia yang biasa terdapat pada pintu masuk menuju candi-candi di Jawa, yatu Kala [11]. Kala berukuran cukup besar di pasang pada bagian atas dari 'tabung' dan berada tepat ditengah-tengah tabung dan diberi warna emas (gold).

Ornamen Kala teresebut menampilkan mata melotot, mulut menyeringai, taring tajam serta juluran lidah, seperti pada gambar 24.

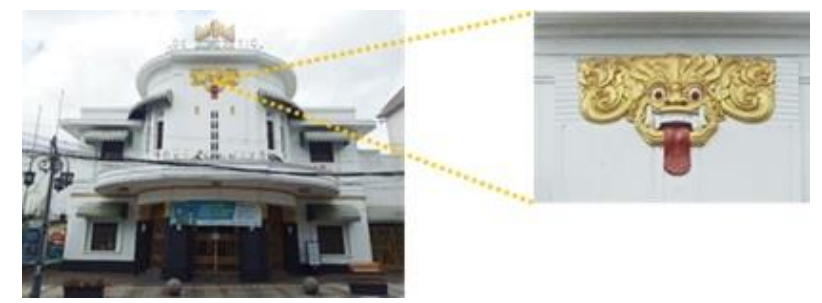

Gambar 24. Ornamen Kala pada Gedung De Majestic

Sumber: hasil analisis, 2020 [7]

Pada beberapa karya arsitektur lainnya seperti Van Dorp Office Bookshop and Print Shop, Burt Myrtle \& Co Office Building, Jacobson, v.d. Berg \& Co. Office Building serta Transformer Kiosk, Schoemaker ternyata menerapkan pula ornamen Kala. Sama seperti pada gedung De Majestic, ornament Kala pada bangunan-bangunan tersebut memiliki ukuran yang cukup besar dan dipasang pada bagian atas dari fasad bangunan (gambar 25). 

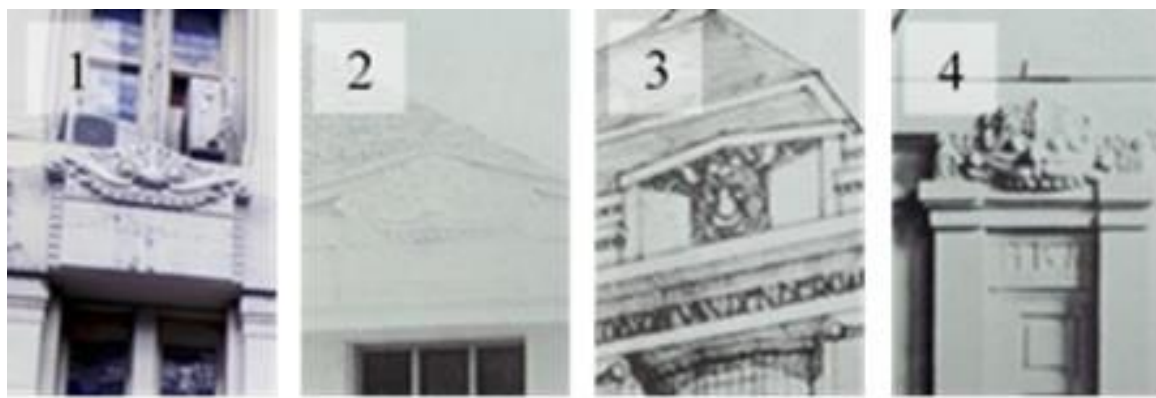

Gambar 25. Van Dorp Office Bookshop and Print Shop (1), Burt Myrtle \& Co Office Building (2), Jacobson, v.d. Berg \& Co. Office Building (3), Transformer Kiosk (4)

Sumber: Tropical Modernity "Life and Works of C.P. Wolf Schoemaker [2]

\section{e. Ornamen Floral}

Selain Kala ornamen lainnya yang diambil dari arsitektur lokal Indonesia adalah ornamen floral. Pada gedung De Majestic ornamen floral ditampilkan kedalam beberapa bagian atau kepingan-kepingan kecil yang diletakkan di beberapa area fasad, seperti di bagian bawah ornament Kala serta diatas maupun dibawah jendela pada lantai dua, seperti terlihat pada gambar 26.

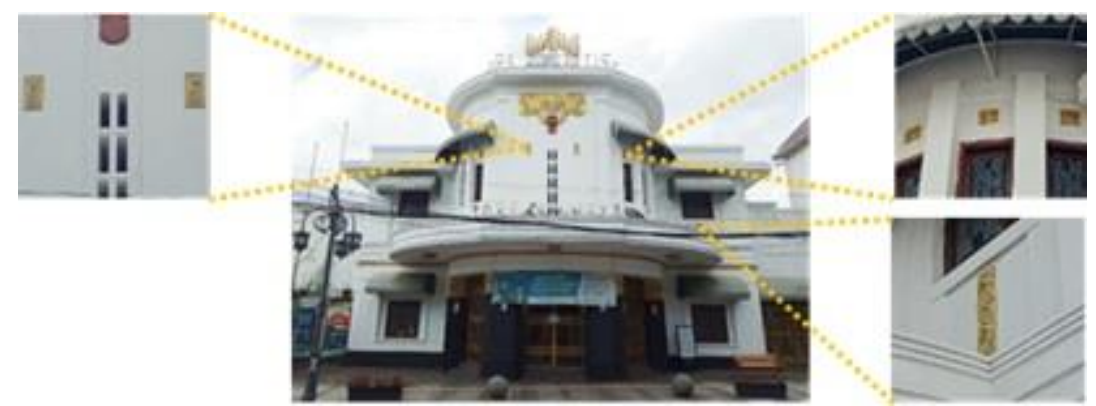

Gambar 26. Ornamen Floral pada Gedung De Majestic

Sumber: hasil analisis, 2020. [7]

Penggunaan ornamen floral pada gedung De Majestic ternyata diulang oleh Schoemaker pada gedung Van Dorp Office Bookshop and Print Shop (Bandung), Van Dorp Office Bookshop and Print Shop (Surabaya) serta Oei Tjong Ham Bank. Tampilan dan penempatannya bermacam-macam, pada beberapa bangunan ornamen floral ditampilkan kedalam bagian-bagian kecil, ditempatkan hanya di satu posisi serta ditampilkan secara menerus mengelilingi fasad bangunan (gambar 27).
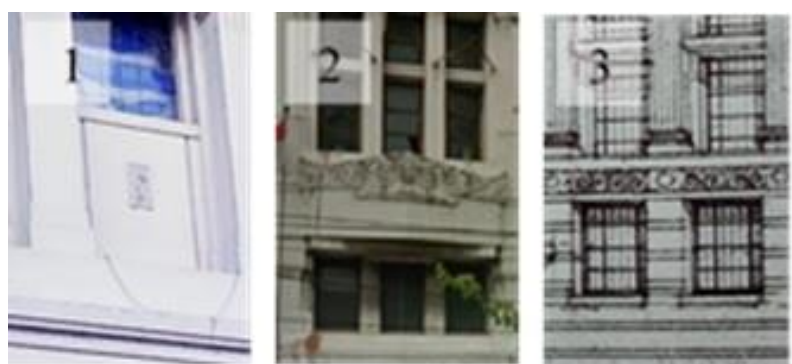

Gambar 27. Van Dorp Office Bookshop and Print Shop Bandung (1), Van Dorp Office Bookshop and

Print Shop Surabaya (2), Oei Tjong Ham Bank (3)

Sumber: Berbagai Sumber

\section{f. Lampu}

Saat ini, pada gedung De Majestic terlihat adanya beberapa lampu penerangan yang disimpan ke dalam kotak serta terpasang pada bagian teritisan dan kolom utama. Kotak lampu tersebut merupakan salah satu elemen fasad yang ditambahkan sekitar tahun 2010 oleh pihak pengelola gedung sehingga penerapan kotak lampu tidak dapat diklasifikasikan sebagai elemen arsitektur khas C. P. Wolff Schoemaker (gambar 28). 


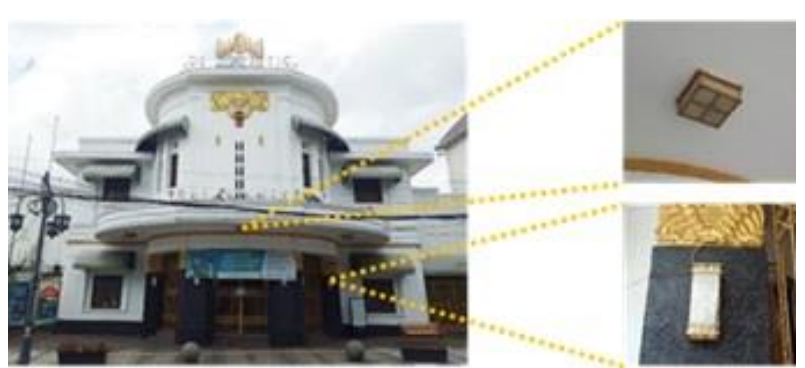

Gambar 28. Lampu pada Gedung De Majestic

Sumber: hasil analisis, 2020. [7]

\section{SIMPULAN}

Gedung De Majestic merupakan hasil karya C.P Wolff Schomaker pada periodisasi ke 2 yaitu antara tahun 1922 sd 1925. Pada periode ini Schomaker mulai memadukan unsur lokal arsitektur tradisional Indonesia dengan gaya arsitektur Eropa. Karakter Eropa pada gedung De Majestic terlihat dari ukuran, bentuk geometris bangunannya dan penempatan pintu jendela yang dibuat simetris antara bagian kanan dan kiri bangunan. Unsur simetris dipertegas dengan deretan vertikal lubang angin yang menyerupai garis sumbu yang membagi bangunan menjadi dua bagian dengan seimbang.

Adapun unsur lokal yang diterapkan pada gedung ini adalah Kala berukuran besar dan berwarna emas (gold) pada bagian atas fasad bangunan sebagai aksen. Sedangkan ornamen floral ditempatkan di bawah kala dan pada kusen jendela sebagai ornamen estetika. Dari data yang diperoleh dapat disimpulkan bahwa dua oramen ini, kala dan floral adalah elemen baru yang diterapkan Schoemaker tidak hanya pada gedung De Majestic tetapi juga pada karya-karyanya di periode ke 2 . Oleh karenanya dapat disimpulkan bahwa karakteristik fasad gedung De Majestic dapat mewakili karakter dari karya C.P Wolff Schoemaker di periode ke 2 yaitu dari tahun 1922 hingga tahun 1925.

\section{DAFTAR PUSTAKA}

[1] Ashadi, Teori Arsitektur Zaman Klasik. Jakarta: Arsitektur UMJ Press, 2020.

[2] C. J. Dullemen, Tropical Modernity: Life and Work of C.P. Wolff Schoemaker. Amstredam: SUN, 2010.

[3] G. Wibisana, "Mitos Kala dalam Arsitektur Wolf Schoemaker pada Gedung Landmark Bandung,” J. Ilm. Seni Budaya Pantun, vol. 5, no. 1, 2020.

[4] H. Kunto, Wajah Bandoeng Tempo Doeloe. Bandung: Granesia, 1984.

[5] "Bioskop Majestic/New Majestic I Info Pikiran Rakyat." [Online]. Available: http://info.pikiran-rakyat.com/?q=direktori/gedung-pertunjukan/kota-bandung/bioskopmajesticnew-majestic. [Accessed: 24-Feb-2021].

[6] Krier. Rob, Elements of Architecture. London: Academy Group LTD, 1983.

[7] R. Nuryadi, I. Apriyandi, A. Akbar, Identifikasi Elemen Arsitektur Khas C. P. Wolff Schoemaker pada Fasad Gedung De Majestic, Laporan Seminar Arsitektur, Prodi Arsitektur, Fakultas Arsitektur dan Desain, Itenas, Bandung. 2020.

[8] “Gpibbethel's Blog.” [Online]. Available: https://gpibbethel.wordpress.com/. [Accessed: 24Feb-2021].

[9] “majesticb.jpg (500×500)." [Online]. Available: https://mooibandoeng.files.wordpress.com /2013/06/majesticb.jpg. [Accessed: 24-Feb-2021]

[10] https://twitter.com/DeMajesticBdg/status/948440342407213057/photo/1 [Accessed: 24-Feb2021]

[11] Sumadi, Ragam Hias Kala Sebagai Katya Seni Rupa. Jurnal Ornamen, 8 (1), 64-96, 2011. 